\title{
REGULATION OF RETURNS TO TRANSPORTATION AGENCIES
}

\author{
NeISON LeE SMITH*
}

Regulation of the rates and fares of transportation agencies-like public control of the charges of public utilities, such as electric, gas, telephone, and water companies -manifests itself in two distinct, but interrelated, aspects: (I) determination of the permissible level of net earnings; and (2) establishment of the individual prices of the various services furnished, from which the revenues of the enterprise are derived. It is to the former that this article is addressed.

This is not to suggest that the problems of pricing specific services are any less difficult or less important, either to the public or to the enterprise. They give rise to a variety of economic and legal issues, involving allocations of costs, relative elasticities of demand and values of service, and questions of undue discrimination, prejudice, or preference, which can become quite complex and which, because of their competitive impacts upon the supplier and the user of the service, can be highly significant to both. Resolution of these issues ordinarily calls for latitude in the exercise of managerial ingenuity in the development of measures adapted to the circumstances of each situation, with the minimum of regulatory restraint required to prevent demonstrably uneconomic practices or unfairness to the public. But, however particular pricing situations may be decided, the over-all yield of the aggregate charges collected must be sufficient to cover all the costs of performing the service, including a net return to the owners of the business which, while not excessive when compared with results in similar undertakings, will induce capital to remain or flow into it in amounts adequate to maintain its economic health and to permit the growth which its role in the national economy requires.

Determination of the earnings levels which will meet these tests and merits of various measures used in such determination are matters which have been of major and continuing concern to regulatory agencies, courts, practitioners, business executives, financiers, and students of transport and public-utility economics since the early days of regulation in the United States. Extension of regulation into additional fields, the increasing complexity and time-consuming nature of regulatory pro-

\footnotetext{
*A.B. 1921, Dartmouth College; M.C.S. 1922, Amos Tuck School; Ph.D. 1928, University of Michigan. Vice President, American Airlines, Inc., since 1955. Formerly Professor of Economics, Dartmouth College 1921-37; Member, New Hampshire Public Service Commission, 1933-4I, Chairman, 1934-41; Chairman, Board of Investigation and Research-Transportation, 1941-43; Member, Federal Power Commission, 1943-55, Chairman, 1947-50; President, New England Association of Utility Commissioners, 1936; President, National Association of Railroad and Utilities Commissioners, 1938-39. Author, The FaIR RAtr of Return in Public Utility Regulation (1932); co-author [with Bruce W. Knight], Economes ( 2 vols., I 929 and 1930). Contributor of various articles on transportation and public utilities in economic and business publications.
} 
cedures, and the sustained inflationary pressures upon costs in recent years-which have led to rate-increase proposals reversing downward trends which had long prevailed in many regulated areas-all have operated to focus attention anew upon this aspect of rate regulation.

\section{I}

\section{Regulation in a Free Enterprise System}

Traditionally, the establishment of regulatory controls in this country has been based on public acceptance of the view that the "invisible hand" of competition could not, for one reason or another, be fully relied upon to protect the public interest in the furnishing of services deemed essential to the individual and to the national welfare. The Granger legislation of the 1870 's and adoption of the Act to Regulate Commerce in $1887^{1}$ reflected public reaction to the monopoly power and abuses of the railroads in their virtually indispensable function of moving the products and commerce of a rapidly expanding economy. Likewise, the extension of similar regulatory controls at the state level to our major types of public-utility enterprises during the early years of the present century resulted from fears, or demonstrations, of the abuse of monopoly power by these essential businesses, which were often entrenched in their positions by grants of exclusive franchises. Subsequent additions of new types of businesses to the regulated group-such as the motor carriers and airlines in the transportation field-took place as they proved their value; assumption by the federal government of increasing regulatory responsibilities-in such areas as electric utilities, natural-gas pipelines, communications, and commercial aviation-reflects the growth of the interstate operations of these enterprises, the inherent limitations upon the ability of the states to control them effectively, and the predominance of the national interest, rather than any basic changes in the objectives and underlying philosophy of regulation.

In the light of this historical background, it is not surprising that the regulatory agencies have tended to carry over, at least initially, principles and procedures developed in older areas of control to enterprises newly added to the regulated group. This was largely true when the Federal Power Commission embarked upon the regulation of interstate natural-gas pipelines by applying precedents developed in the field of electric utilities, and when the Civil Aeronautics Board began its control of mail rates and subsidy payments by using, essentially, the "fair return" approach generally followed in public-utility regulation. Likewise, the emphasis upon rigid restriction of earnings to minimum levels is more understandable when regulation is thought of simply as a substitute for the beneficent action of classical competition in preventing the emergence of monopoly profits.

While such tendencies may be the natural outgrowth of an evolutionary process, they can become dangerous unless tempered by continuing examination of the economic characteristics and all the surrounding circumstances of the subject business.

\footnotetext{
124 Stat. 379,49 U.S.C. $\$ \S$ I et seq. (1952).
} 
Such analysis may disclose departures from the assumed norm of public-utility behavior or the presence of competition to a degree sufficient to justify-and, in fact, to require-some relaxation of the urge to hold down profits through the imposition of unrealistically low ceilings fixed by public authority in accordance with out-moded concepts.

In our free-enterprise system, capital is not commandeered or moved by fiat from one employment to another. It is the opportunity to earn attractive profits, or to incur loss, that directs the flow of funds, whether in the form of new savings by individuals or institutions or in terms of dollars generated by businesses in the course of their operations, which are available either for re-investment in replacements or extensions of existing activities or for diversion into other activities. Thus, in the economy generally, the profit opportunity serves not only as a powerful incentive to internal efficiency, but also to monitor the flow of capital as among alternative uses.

Because of their obligations to render adequate service to the public, the transportation agencies and utilities are somewhat less free to alter the nature and extent of their operations than are the unregulated industries. And in some instances, as in the case of the railroads, a relatively high proportion of long-lived items of fixed plant may further inhibit the mobility of capital assumed in economic theorizing regarding the functions of the market place. Nevertheless, the capital outlays required in the regulated areas are of huge magnitude. Thus, the private electric utilities of the United States spent nearly $\$ 4,000,000,000$ on construction in $195^{8}$, and by 1975 expect to have expended upwards of $\$ 100,000,000,000$, in terms of $195^{8}$ prices, to treble the size of the industry. ${ }^{2}$ The natural-gas industry spent about $\$ 2,000,000,000$ on new capital additions in $195^{8}$ and estimates additional requirements to 1970 at $\$ 33,500,000,0000^{3}$ In the communications field, the Bell System alone spent $\$ 2,200,000,000$ on construction in 1958 , of which $\$ 1,377,000,000$ represented new capital. ${ }^{4}$ Gross capital expenditure for road and equipment by Class I railroads in 1958 amounted to $\$ 700,000,000$ and are expected to be only slightly less in $19590^{5}$ Outlays by other transportation agencies are estimated at $\$ 1,500,000,000$ in 1958 and $\$ 1,900,000$,ooo for $1959 .{ }^{6}$ Conversion of the airlines to jet operations calls for outlays for flight and related ground equipment in the order of $\$ 2,000,000,000$ by the end of 1961 ; at the end of $x 958$, the firm orders of the domestic trunklines for additional aircraft and engines alone aggregated more than $\$ 1,380,000,000$. $^{7}$

Measured against the $195^{8}$ capital outlays of all American business-which approached $\$ 31,000,000,000-$ the investments of the regulated utilities and transportation agencies amounted to about one-third of the total. There are no indications that their capital requirements will become a significantly smaller factor in the national economy within the foreseeable future. Clearly, therefore, if these enterprises are to

\footnotetext{
'Address by Robert S. Quig, Trends in Regulation, before the New York Society of Security Analysts, Jan. 2I, 1959, p. I.

${ }^{3}$ Ibid.

- American Telephone and Telegraph Co., Ann. Rep., 1958, at 2.

Transport Economics, March I959, p. x.

'Aviation Daily, April 3, 1959, p. 247.

'Transportation, March 31, 1950.
} 
secure the capital which they require, they must be able to afford investors opportunities for returns which are attractive when compared in all respects with those available from alternative uses to which their funds may be put.

\section{II}

\section{The Fair-Return Doctrine}

This truism-recognition that in our free economy all uses of capital compete for funds in the marketplace-underlies the development of the concept of the "fair return" from $S m y t h$ v. Ames ${ }^{8}$ through the Hope case. ${ }^{9}$ Whether the immediate thrust be the elimination of an unwarranted element of monopoly profit or protection of the regulated business in its opportunity to attract needed capital, the need exists for standards whereby the reasonableness and adequacy of the return to the owners of the property may appropriately be judged.

During the early decades of the present century, the principal points of controversy concerned the determination of the base to which the permissible rate of return should be applied: (I) what elements of property should be included as "used and useful" in serving the public; and (2) how the allowed-items should be valuedwhether in terms of the investment as measured by net original or historical cost, or at the present value of the property, determined by physical appraisals, or, more recently, by some form of statistical trending of asset values, in accordance with indices of pertinent price and cost data. With the passage of time, however, the "prudent investment" rate base advocated by Mr. Justice Brandeis in his separate opinion in the Southwestern Bell Telephone case $^{10}$ gained general acceptance by state and federal regulatory bodies and courts. ${ }^{11}$ And with this shift of emphasis, came in-

${ }^{8} 169$ U.S. 466 ( 1898$)$.

${ }^{\circ}$ FPC v. Hope Natural Gas Co., 320 U.S. 59 I (1944).

${ }^{10}$ In his language: "The thing devoted by the investor to the public use is not specific property, tangible and intangible, but capital embarked in the enterprise. Upon the capital so invested the Federal Constitution guarantees to the utility the opportunity to earn a fair return." Missouri ex rel. Southwestern Bell Tel. Co. v. Pub. Serv. Comm'n, 262 U.S. 276,290 (1923).

${ }^{11}$ Within the last several years, there has been a considerable resurgence of advocacy of the use of "present values," both in the determination of the rate base and in" the computation of depreciation charges, primarily as an offset to the attrition of the investment rate base under the pressures of continued inflation and the rising costs of replacements in kind under such conditions. See, e.g., Guercken, Regulation in the Age of Inflation, Electric Light and Power, Feb. 15, I959, pp. 53-57. And such efforts have met with some success in certain instances. E.g., Iowa-Illinois Gas and Electric Co. v. City of Fort Dodge, 20 P.U.R.3d 159 (Iowa 1957); Missouri Water Co. v. Pub. Serv. Comm'n, 22 P.U.R.3d 254 (Mo. 1957).

It is, of course, true that powerful arguments can be marshalled from classical economic theory in support of using the present values of capital items currently required for production in computing the marginal costs, and prices, of goods sold in competitive markets, although it must be remembered that these values and costs would relate to a plant which might now be built by a competitor rather than to the identical plant now in eixstence. Nevertheless, the writer is quite skeptical of the probable success of such efforts on any very general basis. It would appear rather unrealistic to expect the regulatory bodies, after many years of persuading themselves, the courts, and the public of the virtues of the "prudent investment" approach in terms of administrative simplicity, certainty, stability, and the like, to reverse themselves completely and adopt procedures of valuation which they have condemned as hypothetical and wasteful. Likewise, the concept of depreciation as amortization of cost seems.so firmly 
creased attention to the equally important factor in the fair return-equation, the rate of return, which hitherto had been given scant analysis in the literature of rate regulation. Accordingly, the thrust in most areas of regulation has been directed increasingly toward efforts to find appropriate means of determining the rates at which net earnings on investment should be permitted, which has resulted in the widespread use of "cost of capital" studies for this purpose. Additionally, in the case of businesses-such as the motor carriers and airlines-where the ratio of annual expenses and revenues to fixed investments is so high as to make the net return a much smaller factor in the total cost of service than is true of most public utilities, there has developed a growing concern in the maintenance of an adequate margin of profit per revenue dollar, which has led to the advocacy and use, in some areas of regulation, of the operating ratio, or "all-expense" ratio, ${ }^{12}$ as a test of the required level of charges.

As the Supreme Court pointed out in the Hope case, however, it is the "end result," not the method of reaching it, that is important as a matter of law; and this is equally true as a matter of economics. What is important-alike to the regulated enterprise and to the users of its service-is that there be an opportunity for earnings sufficient to attract capital, in competition with alternative investment opportunities, in amounts adequate to provide the volume and quality of service which the public requires. This is no more nor less than the principle stated by the Court in the Bluefield case, ${ }^{13}$ when it recognized explicitly that fair rates of return must varyfrom time to time, from place to place, and from utility to utility-in order to reflect the relative risk inherent in the business and current conditions in the money market and economy generally.

imbedded in accounting and regulatory practice as to make unlikely the widespread acceptance of "cconomic depreciation" in rate-making.

This is not to say that studies of the present values represented by the property under consideration, and reconstructions of its depreciation accounts to show what would be needed to provide for replacement at current price levels, are without valuc in rate-level proceedings. On the contrary, they can be very useful in demonstrating to the agencies the impact of inflation and the necessity, therefore, for a carcful look into the future, as distinguished from preoccupation with the past, in applying whatever principles and procedures they utilize in prescribing rates. But this is a different thing from expecting them to adopt the concepts of "present value" and "economic depreciation" per se.

${ }^{12}$ Including depreciation and all taxes with the operating expenses, but excluding interest, so that the resulting margin of profit corresponds in composition with the elements covered by the "fair return."

${ }^{13}$ Bluefield Water Works \& Imp. Co. v. Pub. Serv. Comm'n, 262 U.S. 679 (1923). The pertinent language, at p. 692 , is as follows:

".... A public utility is entitled to such rates as will permit it to earn a return on the value of the property which it employs for the convenience of the public equal to that generally being made at the same time and in the same general part of the country on investments in other business undertakings which are attended by corresponding risks and uncertainties; but it has no constitutional right to profits such as are realized or anticipated in highly profitable or speculative ventures. The return should be reasonably sufficient to assure confidence in the financial soundness of the utility and should be adequate, under efficient and economical management, to maintain and support its credit and enable it to raise the money necessary for the proper discharge of its public duties. A rate of return may be reasonalle at one time and become too high or too low by changes affecting opportunities for investment, the money market and business conditions generally." (Emphasis added.) 
From the standpoints, therefore, of both law and economics, it follows that there can be no such thing as a single, fixed rate of return which is fair for all time or for all types of regulated enterprises, regardless of the investor's evaluation of the relative risks or attractiveness of each under the circumstances prevailing at the time. The fact that a return of six per cent on the net investment of an electric or gas utility in r 948 may have been entirely reasonable does not mean-or even suggest, without close comparative analysis of each situation-that this level of net earnings would be appropriate for an airline or motor carrier in the same year, or for any of these businesses ten years later.

Although rates of return allowed public utilities have tended to cluster within rather narrow ranges-with something in the order of six per cent for electric, gas, and telephone companies, and slightly less for water utilities, being fairly typical during the years since World War $\mathrm{II}^{14}$-there is nothing in the history or present status of the "fair return" concept which compels uniformity in this respect. Nor is there anything inherent in the "prudent investment" doctrine to support the exclusion of items of capital investment which have been honestly made in accordance with good business judgment and the requirements of the industry and times simply because, under different circumstances, items having apparent similarity to those in question may have been disallowed in the past. Finally, there is nothing in the development of regulatory principles to require that attention be limited mainly to the past, without realistic consideration of future probabilities-as to rate base, rate of return, and operating expenses, which must also be recovered from the public through the levels of charges collected for service-when rates are being fixed for application during a future period.

In sum, it is the writer's view that there is-or can and should be-sufficient flexibility in the implementation of our basic regulatory concepts, as they have evolved under the "fair return" doctrine, to meet the exigencies and economic requirements of the time and place. If there is failure in this respect, it is not the fault of the principles themselves, but defects in their application. This, in turn, could be due, in considerable degree, to inertia and the illusion that formulae and mechanistic accounting approaches can be substituted for the exercise of informed judgment in ratemaking. To overcome these attitudes and to devise effective means of making fully evident and understandable the distinguishing characteristics which underlie their individual revenue requirements are among the major problems of the regulated industries. In no area is this need more pressing than in the transportation fieldand particularly in the case of the unsubsidized domestic trunk airlines as they now

\footnotetext{
is See Arthur Andersen \& Co., Return Allowed in Public Utility Rate Cases (Supp. No. 2, 1958). In a recent case involving international telegraph traffic, the FCC concluded that a return of as much as $81 / 2$ per cent would be reasonable under all the circumstances. In the Matter of the Western Union Telegraph Co., No. Ir953, Initial Decision Made Final, FCC, July 30, 1958, pp. 76-77, II7. In the regulation of the rates of "independent producers" of natural gas, the FPC has been using rates of return in excess of 9 per cent. See, e.g., Matter of Phillips Petroleum Co., No. G-rr 48, Initial Decision, FPC, April 6, 1959, p. 227, wherein Examiner Zwerdling discussses various approaches to the problem and concludes that $91 / 4$ per cent is fair under the circumstances.
} 
enter upon the jet age. It is with their special problems and the means which they have utilized to demonstrate them that the balance of this article is largely concerned.

III

\section{Surface Transportation Agencies}

Although it is believed that the present situation of the major domestic commercial airlines will afford timely and pertinent illustrations of many of the problcms here under consideration, it would perhaps be well first to allude briefly to certain highlights in the recent history of rate-level regulation of other transportation agencies by the Interstate Commerce Commission.

In the case of the railroads, it has been years since there has been a determination of the general level of freight rates or passenger fares in terms designed to yield a fair return on investment. The effort has been to keep the level of charges in some kind of balance with constantly rising costs. Thus, in its 1957 opinion allowing general class rate increases amounting to twelve per cent and increases in other basic charges which were equivalent to fourteen per cent, twelve per cent, and nine per cent within the Eastern, Western, and Southern Territories, respectively, the ICC came to no conclusions regarding a proper return on investment. ${ }^{15}$ After discussing at length various experienced and anticipated increases of costs, it pointed out that the permitted rate increases would simply recover estimated cost increases, and would have no undue adverse effect on the movement of traffic. It also referred to its statement some five years earlier that "judged by any standard, the rates of return earned or prospectively to be earned by the railroads ... are substandard."16

Similarly, in permitting permanent increases of five per cent in coach fares and twenty per cent in first-class fares in Official Territory, again in 1957, the Commission's action was taken because the higher fares "will yield a substantial increase in revenue, of which the carriers are in need and to which they are justly entitled" and "are necessary in order that travel thereunder may make a fairer contribution to the revenues needed ...,, 17 in view of the passenger deficits shown on the record, rather than in terms of a fair return on investment.

In its regulation of motor carriers, also, the ICC has found it appropriate to depart from, or at least to supplement, the conventional "fair return" method by gearing the rate levels and returns allowed to their profit margins, or all-expense operating ratios -primarily because of their high rates of capital turnover (i.e., high ratios of annual revenues and expenses to fixed investment) ${ }^{18}$

${ }^{15}$ Increased Freight Rates, Eastern, Western, and Southern Territories, 1956, 300 I.C.C. 633 (1957).

${ }^{10}$ Increased Freight Rates, 1951, 284 I.C.C. 589, 612 (1952).

${ }^{17}$ Increased Fares, Official Territory, 1956, 300 I.C.C. 239, 255 (1957). Sce also Railroad Passenger Train Deficit, No. 31954, Examiner's Proposed Report, ICC, Sept. 18, I958.

${ }^{18}$ Increased Common Carrier Truck Rates in the East, 42 M.C.C. 633 (1943). 
The Commission has explained its position as follows: ${ }^{19}$

In industries where the amount of investment is large in relation to total costs, the rate of return on investment generally has been accepted as appropriate for determining revenue needs. In such industries the risk is related more to the investment and less to costs. On the other hand, where the amount of the investment is relatively small in relation to total costs, investment is not the primary factor in determining revenue needs. . . . The owners of motor carriers can hardly be expected to look to the return on the amount of their investment as an incentive where the principal risk is attached to the substantial greater amount of expense. This is not to say that the rate of return on investment, comparisons of net income to capital stock, of the relation of debt-free property to capital stock, and other financial comparisons or studies are not useful in an appraisal of the financial condition and progress of the motor carrier industry. But for the purpose of determining the need of increases in rates, the criterion must be the carrier's cost.

Among the state commissions, likewise, there has been a decided trend toward the use of the operating ratio, or profit margin, as the rate-making standard for motor carriers and transit companies. A recent survey of 154 such cases in twenty-three states, the District of Columbia, and Hawaii, between January 1947 and January 1957, showed that seventy-six attached prime importance to operating ratio, with an increasing proportion being decided on this basis toward the end of the period covered (ninety-two per cent in the thirteen months ending with January I957).$^{20}$

Because the typically high rates of capital turnover, low profit margins, and volatile revenues and expenses of the airlines make them resemble more closely, in these respects, the motor carriers and unregulated businesses generally than they do theregulated utilities and railroads, it has been suggested that for the airlines, too, the operating ratio be used as the yardstick in rate-making-either as a substitute for, or as a complement to, the fair-rate-of-return approach. ${ }^{21}$ Indeed, in its early regulation of mail rates, ${ }^{22}$ and more recently in its establishment of subsidy payments for car-

${ }^{10}$ Middle West General Increases, 48 M.C.C. 54I, 552-53 (1948). See also County Bd. of Arlington County v. United States, ror F. Supp. 328, 330-3I (E.D. Va. I95I); Increases, California, etc., 5 I M.C.C. 747, 760-6r (1950); Investigation of Bus Fares, 52 M.C.C. 332 (1950); New England Motor Rate Increases, 66 M.C.C. 215, $218-20$ (1956).

${ }^{20}$ See General Passenger Fare Investigation, No. 8008, American Airlines Exhibit No. 906, CAB, Sept. 13, 1957, and cases cited and excerpts set forth therein. For convenience, this proceeding will hereinafter be cited simply as CAB No. 8008, and American Airlines' exhibits therein as Exhibit No. AA-.

${ }^{21}$ Rickenbacker, The Operating Ratio as a Yardstick for Measuring Airline Profits, 20 J. AIr L. \& Com. 253 (1953). Cf. Grossman, Reasonable Operating Ratio Versus Fair Rate of Return, 21 id. at 15 (1954).

23 "A specified return on' the carrier's investment which would enable that carrier to earn an amount sufficient to cover its capital cost would not be an inflexible measure of the fair and reasonable rate contemplated by the Civil Aeronautics Act; it would, however, constitute significant and valuable evidence to be taken into account in connection with the determination of such a rate. Likewise, the relationship which the carrier's profit bears to its total reventes, would offer some evidence of reasonableness when considered in comparison with similar data of other industries of similar risk. In this connection the ratio between the carrier's investment and the volume of service rendered, when compared with the higher ratio prevailing in other public utilities, would also be a proper subject of consideration." American Airlines, Inc.-Mail Rate Proceeding, 3 C.A.B. 323, 337 (1942). (Emphasis added in the last twosentences.) 
riers with particularly small rate bases, ${ }^{23}$ the Civil Aeronautics Board has indicated that such a technique has its place.

There is, in the opinion of the writer, no fundamental conflict between the rate-ofreturn and the operating ratio, or profit-margin, approaches to rate-making. They are obviously, and arithmetically, interrelated; if any two of the three factors-capital turnover, profit margin, and rate of return-are given, the third is, in fact, predetermined. ${ }^{24}$ Either method, can produce the same dollar return. As will appear below, each can perform a useful function in determining the proper level of airline earnings.

\section{IV}

\section{The Atruine Fare Case}

As indicated earlier, the principal domestic airlines are now engaged in a major effort to demonstrate the peculiar economic characteristics of their business which should be taken into account in determining their revenue needs and the manner in which and the level at which a fair return should be established for them. This is in the General Passenger Fare Investigation, which was initiated by the $C A B$ in mid-1956. ${ }^{25}$

\section{A. Background ${ }^{26}$}

As background for this proceeding, it should be borne in mind that at the end of World War II, the airlines were just emerging as a major factor in the nation's transportation system. In 1946 , the domestic trunklines as a group ${ }^{27}$ had an investment of $\$ 219,600,000$. Their service was provided principally with DC-3 arrcraft costing about $\$ 125,000$ each, seating twenty-one passengers, and cruising at a speed of around 150 miles per hour. The $\mathrm{DC}_{-4}$, which cost $\$ 450,000$, carried sixty-five passengers at a cruising speed of 180 miles per hour, and could make a transcontinental

${ }^{23}$ E.g., Allegheny Airlines, Mail Rates, No. 6620, Order No. 9009, CAB, March II, 1955, pp. 10-II; Central Airlines, Mail Rates, No. 4097, Order No. E-9669, CAB, Oct. 18, 1955, p. 8; West Coast Airlines, Mail Rates, No. 6391, Order No. E-10315, CAB, May 24, 1956, pp. 14-15.

${ }_{2 s}$ Dr. Herbert B. Dorau, testifying for Eastern Air Lines, Inc., expressed these relationships as follows, with $R$ representing the rate of return, $C$ the rate of capital turnover, and $M$ the margin of profit (reciprocal of all-expense ratio):

$$
\begin{aligned}
& R=M C \\
& M=\frac{R}{C} \\
& C=\frac{R}{M}
\end{aligned}
$$

Thus, as he illustrated the matter, if the invested capital is twice the annual revenue (a capital turnover rate of 0.5 ) and the margin of return is $20 \%$ (an all-expense ratio of $80 \%$ ), the rate of return must bc 10\%. CAB No. 8008, Eastern Air Lines Exhibit No. I-R, Oct. xI, x957, p. 7.

${ }^{25}$ CAB No. 8008, Order No. E-r0279, May ro, 1956.

${ }^{20}$ The airline statistical data used throughout this section are derived from the Form $4 \mathrm{r}$ reports filed by the air carriers with the CAB.

${ }^{27}$ Now consisting of the following carriers: American, Braniff, Capital, Continental, Delta, Eastern, National, Northeast, Northwest, Trans World, United, and Western. 
trip with two stops in about fourteen hours, was just coming into commercial service. In 1946, the trunklines carried domestically almost I2,000,000 passengers for a total of $5,900,000,000$ revenue-passenger-miles (less than 6.5 per cent of the total intercity common-carrier market). They also transported some $71,000,000$ ton-miles of mail and cargo. Their operating revenues, of which eighty-eight per cent came from passenger traffic, amounted to about $\$ 3 \mathrm{II}, 500,000$, and they suffered a net loss, after taxes, of over $\$ 6,000,000$. Nine of the sixteen then-existing trunkline systems received subsidy, aggregating $\$ 5,000,000$.

By 1956 , however, the net investment of the trunklines as a whole had grown to $\$ 900,000,000$, representing a fleet of $\mathrm{I}, 100$ aircraft and the related ground equipment necessary to operate and maintain them. They had introduced Convair and Martin equipment in the shorter hauls; in the longer hauls, they had introduced the DC-6 and the Constellation, followed first by the DC-6B and the Super-Constellation, and then in $1953-54$ by the $\$ 2,100,000$ DC-7, carrying sixty passengers in first-class or eighty-five in coach service at more than 300 miles per hour, and making the transcontinental trip nonstop in an average time (eastbound and westbound) of slightly over eight hours. Cabin-pressurization had been introduced and noise levels reduced, contributing to passenger comfort; many features, including radar, had been added in the interest of safety and dependability; reservation, ticketing, and terminal services were being constantly improved to increase the convenience of air travel; and low-cost coach service had been extended to account for thirty-seven per cent of the total passenger-miles.

During 1956, the domestic trunklines carried 38,000,000 passengers a total of $21,600,000,000$ passenger-miles, an increase of 267 per cent over 1946 , accounting for over thirty-four per cent of the intercity common-carrier market. This represented an annual growth rate of approximately fourteen per cent, as compared with 3.7 per cent for the economy as a whole, measured by Gross National Product adjusted to constant dollar values. Mail ton-miles had increased by 180 per cent to 92,000,000. Cargo and express accounted for $240,000,000$ ton-miles, an increase of 485 per cent over 1946. Operating revenues amounted to $\$ 1,300,000,000$, of which ninety-two per cent came from passenger traffic. Net earnings after taxes were $\$ 58,000,000$ in 1956 , as compared with a $\$ 6,000,000$ loss in I946. Before interest and net gains on the sale of equipment, the 1956 composite return of the domestic trunklines was nearly nine per cent on their net domestic investment averaged for the year. Just three of these carriers received subsidy, totaling only $\$ 2,600,000$; and it was hoped that such payment to this segment of the industry could soon be eliminated completely.

The growth record of the airlines during this period is the more remarkable when it is realized that their expansion had been financed in large part from depreciation throw-off and retained earnings, with but relatively little resort to outside sources of funds. In 1956 , for example, the trunklines retained in the business some $\$ 37,000,000$, or about half of their net income from operations. Furthermore, through improved technology and managerial techniques, they had been able to overcome the sub- 
stantial rise of the prices of the goods and services which they have to buy to operate and which have been under continuing inflationary pressures since I946. Trunkline costs per available ton-mile (the unit of production) had been cut from over thirtytwo cents in 1946 to 26.5 cents in 1956 , and costs per revenue-ton-mile (the unit of sales) from nearly fifty cents to forty-seven cents.

The general fare level, as measured by average revenue per passenger-mile, stood at 5.28 cents for the trunklines in 1956 , which was approximately its 1942 level. Although first-class fares had increased slightly, from 5.28 cents to 5.87 cents, this was offset by the expansion of coach service at an average yield of 4.28 cents in 1956 . All this was in striking contrast to the movement of the prices of other transportation services and of commodities generally. Over the same period, average rail fares had increased thirty-nine per cent, intercity bus charges had risen twenty-nine per cent, wholesale prices had gone up seventy-nine per cent, and the cost of living, as represented by the Department of Labor's Consumer Price Index, had advanced by sixtyseven per cent.

\section{B. Impacts of the Jet Age}

Meanwhile, rapid strides were being made in the adaptation of the turbine engine to economical airline use. By 1955 , the major airlines were beginning to place large orders for turbine-engined equipment, which not only promised new standards in the speed and comfort of air travel, but also confronted the airlines with problems of re-equipment financing which dwarfed anything that they had faced in the past.

The propeller-driven jet, as typified by American's version of the Lockheed Electra, costs in the order of $\$ 2,500,000$ and carries sixty-eight passengers at about 400 miles per hour in the shorter hauls. The jet-driven equipment-including the Boeing 707 , the DC-8, and the Convair 880 and $600-$ is designed for the longer hauls, costs upwards of $\$ 5,000,000$, seats roo passengers or more, and will cruise at speeds up to more than 600 miles per hour. With the jet, the time of the transcontinental nonstop trip is cut by forty per cent. Thus, at one stroke, an advance in speed is being accomplished equal to that achieved in the entire period since the introduction of the $\mathrm{DC}_{3}$ in 1936. In addition, these new aircraft afford great improvements in passenger comfort, through reduction of cabin noise and vibration, better air-conditioning and ventilation both in flight and on the ground, more efficient baggage-handling, and the like. At the same time, the necessary maintenance facilities are being provided, terminals are being enlarged, and passenger reservation, ticketing, and handling procedures are being geared to match the speed and capacity of the jet equipment.

Highest official notice has been taken of the great importance of these improvements-in terms of service to the public, airline and general economic welfare, and the national defense-and of the successful transition of the airlines to the jet age. ${ }^{28}$ To provide them, however, will require capital outlays which, in terms of firm

${ }^{\text {28 }}$ Cherington, Airline Equipment Investment Program, H.R. Doc. No. 430, 85th Cong., 2d Sess. (r958). 
orders placed by the domestic trunklines to date, will amount by $196 \mathrm{x}$ to upwards of $\$ 2,000,000,000$. To place this figure in perspective, it is over $\$ 500,000,000$ more than the total outlays of these airlines for flight and ground equipment during the entire period, 1945-56; it is double their aggregate net worth at the end of 1956 . And it is by no means unlikely that this sum will be substantially increased by further equipment orders before the transition to jet operations is fully accomplished. ${ }^{29}$

It was apparent, therefore, that even with earnings at the relatively favorable levels then prevailing, substantial outside financing would be required. Fortunately, the remarkable physical growth of the airline industry and the more satisfactory level and greater stability of earnings during the years $195^{0-55}$ made it possible for at least some of the stronger domestic trunklines to resort successfully to institutional borrowing. Thus, American was able to negotiate insurance company loans of $\$ 75,000,000$ at four per cent in November 1955, and $\$ 60,000,000$ at $4 \frac{1 / 4}{4}$ per cent in September $195^{6}$. Other carriers were able, likewise, to arrange for a portion of their re-equipment financing through long-term loans, bank credits, and in a few instances through a limited amount of equity financing. Much more remained to be done, however. As late as June 1958 , it was estimated that, giving effect to a projected flow of funds from all sources and assuming earnings at the rate of nine per cent on invested capital, the domestic trunk lines needed to arrange at least $\$ 636,000,000$ of additional financing to cover their firm commitments, which were deemed subject to still further upward revision. ${ }^{30}$

\section{Initial Stages of Proceeding}

This was the setting in which the General Passenger Fare Investigation was launched in May 1956. The vigorous growth of the industry as a whole and the improved earnings position of the major carriers seemed to indicate an approach to a degree of financial maturity which, if these conditions could be continued, gave some promise of appeal to the investor. At the same time, the airlines faced a reequipment program of a magnitude unparalleled in their history; and this gave unusual emphasis to the importance of maintaining their financial health.

During the early part of $195^{6}$, the CAB had been subjected to severe criticism by a congressional committee for its failure ever to have carried through to a conclusion any general investigation of the level of passenger fares or to have established guiding

\footnotetext{
${ }^{30}$ Although some of the required capital outlays, as in the case of airport improvements, are being made by public authorities, and hence are excluded from the total cited, these expenditures are ordinarily to be fully recouped through user payments under leases which give rise to fixed charges upon the airlines. Likewise, certain engine and propeller leases negotiated by airlines with the manufacturers operate to reduce the capital requirements of the airline, but correspondingly increase its annual charges. American, for example, reduced its capital requirements for the r ro turbine-engined aircraft which it has on order and the supporting ground equipment from $\$ 445,000,000$ (nearly $31 / 4$ times its net worth at December $3 \mathrm{I}, \mathrm{I958}$ ) to about $\$ 365,000,000$ by leasing some $\$ 80,000,000$ worth of powerplants and propellers for its Electras and powerplants for its Convair 600's and intermediate Boeing 707-023's. AMERICAN Airlines, INC., ANN. REP., I958, at I, 2, 10.

so Derived from Cherington, supra note 28 , at 27 .
} 
principles in this area of regulation. ${ }^{31}$ Not long thereafter, its order of investigation issued. ${ }^{32}$

The order referred to calculations by the Board's staff showing that in each of the preceding five years, I950-55 inclusive, the trunklines had earned composite rates of return on their average annual net domestic investment of over ten per cent. It stated that unit costs had steadily declined, notwithstanding inflationary pressures on wage rates and the prices of materials, and that load factors during the last three years had become relatively stable at reasonably attainable levels in the range of sixty-three to sixty-five per cent. It cited the consistent and substantial traffic growth over the past ten years as support for the assumption that equally favorable condiditions should continue. It concluded that an investigation into the general level of fares was required, with a view to determining what flat percentage changes in the fares of particular carriers or groups of carriers should be made. At the time, this was widely interpreted as foreshadowing an effort to effect a speedy reduction of airline fares. ${ }^{33}$

Factors were already becoming evident, however, which made both the performance and the outlook much less favorable for the airlines. With testimony and exhibits due to be exchanged early in 1957, and the hearings scheduled to begin in May, seven of the domestic trunklines filed for six per cent emergency increases of their fares, to become effective April I, 1957. ${ }^{34}$ These were promptly suspended and placed under investigation by the Board, ${ }^{35}$ which thereupon, of necessity, deferred further procedural steps in its General Passenger Fare Investigation. On September 25 , 1957, all the proposed emergency increases-estimated to yield some $\$ 67,000,000$ for the domestic trunkline industry as a whole-were found by the Board to be un-

sx "The most noteworthy failure of the Board to justify the presumption that underlies its creation has been in the realm of passenger fares. During its entire existence, the Civil Aeronautics Board has never concluded an investigation of the general level of airline passenger fares. Such an investigation is essential to develop the standards needed to enable the Board to determine whether the fares and charges in use by the airlines are unjust or unreasonable, discriminatory, unduly preferential . . or otherwise unlawful. The failure of the Civil Aeronautics Board to complete a general passenger fare investigation has left a vacuum in its work during its entire existence with respect to the primary rate problems affecting commercial air transportation. On May I0, 1956, the Board started on its fourth attempt to conduct this essential investigation. The committee concludes it is essential that the Board proceed expeditiously in order to remedy as quickly as possible this deficiency in a major area of its responsibilities." Staff of ANtitrust Subcom., House Coma. on the Judiciary, 85Th Cong., ist Sess., Report Pursuant to H. Res. 107, Authorizing the Committee on the Judiciary to Conduct Studies and Investigations Relating to Certain Matters Within Its JuRisdiction, on the Airlines Industry 267-68. (Comm. Print x957).

39 CAB No. 8008, Order No. E-10279, May 10, 2956.

${ }^{33}$ Various lines of inquiry into the fare structure-particularly the relationship of short-haul and longhaul fares-were suggested for inclusion in the investigation. Following the receipt of written comments and oral argument as to the scope of the proceeding, the Board declined to broaden it, emphasizing its desire to proceed promptly with such over-all adjustments as might be indicated if the general fare level should prove to be excessively high. CAB No. 8008, Order No. E-r0488, July 27, 1956.

${ }^{33}$ Braniff, Capital, Delta, Eastern, Northwest, Trans World, and United, with both Capital and Eastern seeking an additional increase of $\$ \mathrm{x}$ per ticket. American subsequently joined in these filings for a $6 \%$ increase, although asserting that the proposed increases were grossly inadequate to meet the real need.

${ }^{35}$ Suspended Passenger Fare Increase, No. 8613, Order No. E-11135, CAB, March 15, I957. 
justified. $^{36}$ The Board recognized that unit costs had risen, profit margins had shrunk, and load factors had fallen, but it optimistically regarded these developments as temporary phenomena. It expressed the view that ${ }^{37}$

... there is little doubt that the drop in earnings which the airlines have reported recently is due in large measure to new aircraft and new routes and the integration and developmental costs which ensue. Once these factors are absorbed into the carriers' operations it is reasonable to expect that their net effect will be higher earnings for the carriers receiving major route awards.

In arriving at its conclusion, the Board invoked both the eight per cent rate of return and the disallowance procedures which it had developed previously in mailrate and subsidy cases. ${ }^{38}$ Thus, for purposes of disposing of that proceeding, it added net capital gains on sales of used aircraft to the operating revenues subject to regulation, eliminated from the rate base the deposits which the airlines had made with manufacturers toward the purchase of new equipment, and lengthened the service lives and increased the residuals used by many of the carriers in calculating their depreciation charges on flight equipment. After making these adjustments, the Board showed 1957 rates of return substantially in excess of those forecast by most of the carriers. ${ }^{39}$

For American business generally, much of 1957 was a good period, and in a physical sense, the airlines shared in this growth. Passengers carried by the domestic trunklines increased to $43,000,000$ for the year and revenue-passenger-miles to 24,500,000,000 , sixteen and thirteen per cent, respectively, above 1956 . Mail and freight also increased, the latter by fifteen per cent. Operating revenues rose twelve per cent, to $\$ I, 420,000,000$. But the upward trend of unit costs, which had become apparent earlier, was even more pronounced. Operating expenses, including depreciation, amounted to $\$ 1,378,000,000$, up nineteen per cent over 1956 . Net earnings from

${ }^{26}$ Id., Order No. E-11812, Sept. 25, 1957, reconsideration denied, Order No. E-12092, Jan. 8, 1958.

${ }^{37}$ Id., Order No. E-1 1812 , Sept. 25, 1957, p. 23.

${ }^{38}$ Early in the history of its determination of mail rates and subsidies, the Board had fixed upon $8 \%$ as the fair rate of return to be used for such purposes. Pennsylvania-Central Airlines Corporation, Mail Rates, 4 C.A.B. 22, 36 (1942). This same rate of return has been used in such cases involving determinations for the future (with $7 \%$ frequently used for past periods) until relatively recently, when, pending disposition of Rate of Return of Local Carriers, No. 8404, Order No. E-10843, CAB, Dec. 10, 1956, $91 \frac{12 \%}{2}$ has been used as the interim fair rate of return, Mohawk Airlines, Inc., Future Final Mail Rate Case, No. 7277, Certification Served, CAB, March 13, I959; New York Airways, Ine., Mail Rates, No. 10365, Order No. E-I3748, $\mathrm{CAB}$, April I6, 1959 .

${ }^{80}$ The rates of return, as forecast by the carriers and adjusted by the Board, are shown as follows in Suspended Passenger Fare Increase, No. 8613, Order No. II812, CAB, Sept. 27, 1957, p. 39, n. 44:

$\begin{array}{llc}\text { Carrier } & \text { Carrier's } & \text { As Adjusted for Depreciation } \\ \text { and Equipment Deposits }\end{array}$


operations declined precipitously, by fifty-eight per cent, to $\$ 42,000,000$, with three of the trunklines reporting deficits. There was growth in volume, but without profit.

Essentially, what was happening was this: After their long postwar record of offsetting rising prices with increased productivity, the airlines saw their costs per available ton-mile increase from twenty-six cents in 1955 to 26.5 cents in 1956 and 26.8 cents in 1957, with no reason in sight to expect a reversal of this trend. At the same time, the impact of the more extensive competition which the Board had authorized during the several preceding years was becoming more apparent and severe. The industry passenger load factor fell from 64.I per cent in 1956 to 61.5 per cent in 1957 . Together, these conditions operated to cause an increase of costs per revenue-ton-mile from 47.4 cents in 1956 to 50.7 cents in 1957. With fares held at their previous levels and an increasing proportion of coach travel (thirty-nine per cent of the 1957 passenger miles), the average passenger-mile yield declined to 5.25 cents in 1957, as compared with a further five per cent increase of rail fares, and with wholesale prices and the Consumer Price Index both rising three per cent above 1956. Airline profits were squeezed between the scissors' blades of rising unit costs and falling unit revenues.

This was the disturbing situation confronting the airlines when the hearings in the General Passenger Fare Investigation opened in mid-November 1957. These hearings continued into the summer of 1958 , and briefs to the examiner were filed that autumn. It is likely to be some months more before the Board finally disposes of the case-perhaps about $3^{1 / 2}$ years after its inception.

Meanwhile, however, some measure of temporary relief has been granted to the airlines. Although it had rejected earlier their plea for an emergency increase of six per cent, the $\mathrm{CAB}$ subsequently recognized the continuing deterioration of earnings in 1957 and permitted an increase of four per cent plus one dollar per ticket, effective February 10, 1958, which, based on 1957 traffic, was estimated by the Board as amounting to approximately $6 \frac{1}{2}$ per cent and yielding about $\$ 85,500,000$ before taxes annually. ${ }^{40}$ Effective October 20,1958 , it permitted the elimination of roundtrip discounts, free stopovers, and certain related routing privileges, as well as a reduction of the family fare discount from fifty to $33^{1 / 3}$ per cent-all of which could yield some badly-needed additional revenue. ${ }^{41}$ And more recently, it has permitted the carriers which inaugurated jet operations to collect small additional charges for that service. ${ }^{42}$ All the tariffs providing for these features were allowed to take effect without suspension, but were placed under investigation, and all were required to bear expiration dates.

${ }^{40}$ Interim Fare Increases, No. 9288, Order No. E-r2203, CAB, Feb. 25, 1958. The Board, howcver, noted that the continued decline of business activity, the downturn of traffic growth, and the evidence of increased unit cost "augur less favorable operating results in 1958." Id. at I0-II.

"In the Matter of Passenger Fares Proposed by the Domestic Trunk Air Carriers, No. 9931, Order No. E-13066, CAB, Oct. I4, 1958, and CAB Press Release No. 58-64, Oct. 14, 1958. On an industry-wide basis, it has been estimated that these changes would increase passenger revenues by some 3.5 per cent.

\$2 E.g., Between New York and Los Angeles, \$10; between New York and Chicago, \$3; and between Chicago and Los Angeles, \$7. 


\section{Main Issues}

From the beginning of the General Passenger Fare Investigation, individual carriers have asked for over-all increases of from $122^{1 / 23}$ to seventeen per cent ${ }^{44}$ above the levels of fares prevailing in 1957. Based on the traffic of that year, it was estimated that a fifteen per cent increase, which is the amount most frequently sought, ${ }^{45}$ would increase industry revenues by about $\$ 193,000,000$ and earnings after taxes by some $\$ 93,000,000$. No member of the traveling public has objected, so far as the.record discloses, to the proposed increases. They have, however, been opposed by the General Services Administration, and with great vigor by the staff of the CAB. Counsel for the Board's Bureau of Air Operations contended at the outset that no increase whatever should be permitted. "Subsequently, this position was modified to concede that, because of the financial problems involved in the transition to jet operations, addition of the four per cent plus one dollar per ticket which the Board had allowed in February $195^{8}$ should be continued through June 30 , r960, and that thereafter a straight four per cent increase over the 1957 fare level should be approved. ${ }^{46}$

In support of their proposals, the different carriers have given varying degrees of emphasis to approaches through the determination of a fair rate of return and through the use of an operating ratio. Thus, United has contended for a return on investment of twelve per cent, with operating-ratio data used only as an indication of the debt ratio which would be supportable. ${ }^{47}$ Eastern, on the other hand, has relied exclusively upon the all-expense ratio, advancing 92.6 per cent, or an operating margin of 7.4 cents, as the proper standard; ${ }^{48}$ and a number of other carriers have given major weight to operating ratios of from eighty-five to ninety per cent. ${ }^{49}$ American has utilized both measures of reasonableness, stressing the need for a twelve per cent rate of return as the primary test, but pointing out also that an operating ratio not exceeding ninety-three per cent is essential; a profit margin of less than seven cents per revenue dollar should be viewed as a danger signal calling for a re-examination of the fare level.

\section{Distinguishing characteristics}

Justification for rates of return about double those which had become traditional in the regulation of public utilities generally was found in the economic characteristics of the airlines, which distinguish them-particularly in the degree of risk involved-

${ }^{13}$ Braniff advocated increases ranging from $121 / 2 \%$ to $18 \%$.

"United; although Capital indicated a need for $20 \%$

¿E American, Continental, Delta, Eastern, and Trans World.

${ }^{10} \mathrm{CAB}$ No. 8008, Brief of Bureau Counsel to the Examiner, Oct. 29, I958.

${ }^{47}$ See, particularly, id., United Air Lines Exhibit No. U-4, Testimony and and Exhibits of David A. Kosh, Oct. 25, I957.

${ }^{48}$ Id., Eastern Air Lines Exhibit No. I-R, Testimony and Exhibits of Dr. Herbert B. Dorau, Oct. Ix, 1957.

'old., Joint Exhibit for Braniff, Capital, Continental, Delta, and Western Air Lines, Exhibits and Testimony of J. Rhoads Foster, Oct. 25, 1957. 
from the conventional types of public utilities. ${ }^{50}$ These factors include the essentiality of the service rendered, the extent of competition present, the rapidity of technological change, the rate of capital turnover and concomitant levels of operating ratio, the vulnerability of airline profits, and the instability of airline earnings. Each will be discussed briefly.

a. Essentiality of service. Although air transportation has gained recognition as playing a very important role in both the economy of the country and the national defense, it can scarcely be thought of as being as indispensable in every day life as are water, gas, electric, and telephone services, which people rely upon and use habitually, virtually taking them for granted as necessities of modern life. In this respect, the business of providing air transportation is inherently more risky than are the conventional public utilities.

b. Competition. Whereas the typical public utility at the local-distribution level is completely free-and at the wholesale level largely free-of competition, the trunk airlines compete intensely not only with other forms of transportation, but also among themselves. The Federal Aviation Act, to be sure, requires authorization of new route operations by the issuance of certificates of public convenience and necessity. ${ }^{\text {GI }}$ But, as interpreted by the $\mathrm{CAB}$ in recent years, these considerations have been deemed to require competition, and frequently multiple competition, in practically every major travel market. Thus, prior to 1955,228 , or nearly sixty per cent, of the 400 largest markets were noncompetitive; while in 1958 , competition had been authorized in 348 , or eighty-seven per cent of these markets. Before r955, only thirty-eight of these city pairs had three or more competing carriers; by $195^{8}$, II 5 , or three times as many, had three or more authorized carriers, while twelve had five or more. In the fifty most important markets, accounting for about forty per cent of the total revenues, the average number of carriers had been increased from two to three..$^{62}$

The presence of such extensive competition in airline operation increases the business risk ${ }^{53}$ and also complicates the task of both the managers and the regulators of the industry-the former, by greatly increasing the difficulty of anticipating demand, planning capacity, and controlling costs; the latter, by creating the question whether rate levels should be adjusted to the needs of the strongest or weakest carriers or a composite of the industry as a whole.

c. Technological change. Without in any way belittling the strides that have been made by the public utilities and other forms of transportation in developing greatly improved techniques of production, the airlines present a unique situation among the regulated industries in this respect. Partly because of their competitive nature,

\footnotetext{
${ }^{\circ 0}$ Id., Exhibit No. AA-6, Testimony of Nelson Lee Smith, and exhibits referred to thercin, Oct. 25, 1957.

52 Stat. 754,49 U.S.C.A. \$ 137 I (Supp. 1958).

52 Cherington, supra note 28, at 18. See also CAB No. 8008, Exhibits Nos. AA-30I-03, Fcb. 27, 1957.

${ }^{53}$ In the Matter of the Western Union Telegraph Co.. No. x1953, Initial Decision Made Final, FCC, July 30, 1958, pp. 76-77, the FCC held that the existence of competition alone warranted the allowance of a rate of return $25 \%$ higher than would normally be allowed noncompetitive utilities.
} 
and partly because of the rapid march of technological development in the field of aeronautics noted earlier, the airlines must place orders for new equipment and related items far in advance of their delivery and at times when many factors bearing upon their performance and the markets which they will serve are necessarily rather speculative. These uncertainties, together with the magnitude of their financial commitments in relation to their present size, combine to give the airlines an appearance of greater-than-normal exposure to risk in the eyes of the investor.

d. Capital turnover and operating ratio. Railroads and utilities, with their relatively heavy investments in items of fixed capital, have typical rates of capital turnover of less than fifty per cent. The airlines, in contrast, turn over their capital about $\mathrm{r}^{3 / 4}$ times per year. ${ }^{54}$ In this feature, they much more closely resemble unregulated industrial companies. ${ }^{55}$ While a high rate of capital turnover is not, by itself, an indication of unusual risk, this does mean that the element of return constitutes a much larger portion of the total cost of production for the railroads and utilities than for the airlines, which, therefore, have a much smaller margin above expenses available for interest, dividends, and re-investment.

The operating ratios of the airlines are much higher than those of other regulated industries. ${ }^{56}$ Obviously, therefore, the earnings of the airlines are more vulnerable and are subject to a greater degree of risk; in this respect, likewise, they are much more similar to industrial enterprises. 57

e. Vulnerability of profits. Because of their combination of rapid capital turnover with high operating ratio referred to just above, the airlines are extremely vulnerable to quite small variations of revenue, expense, or both. To illustrate simply, assume an airline and an electric utility, each earning a six per cent return on an investment of $\$ 100,000,000$, but the former turning its capital over $\mathrm{r}^{3} / 4$ times a year and the latter only once in three years. Reductions of the revenues of the latter by five per cent, with no change in cost, would decrease its return by only 13.3 per cent, to 5.2 per

"4 Average composite ratios of revenues to investment for representative groups of regulated businesses, 1951-56, as shown in CAB No. 8008, Exhibit AA-40x, Sept. 13, 1957, are as follows:

$\begin{array}{lc}\text { Domestic Trunklines } & 178 \% \\ \text { Class I Motor Carriers of Passengers } & 149 \\ \text { Class I Railroads } & 38 \\ \text { American Telephone and Telegraph Co. } & 44 \\ \text { Natural Gas Pipelines } & 37 \\ \text { Class A and B Electric Companies } & 30\end{array}$

${ }^{56}$ Which, for the period $1939-56$, turned over their capital at an average annual rate of $176 \%$. Id., Exhibit AA-469, Sept. 13, 1957, covering 195 representative industrial concerns.

${ }^{50}{ }_{1951-56}$ average composite operating ratios are shown in id., Exhibit No. AA-901, Sept. 13, 1957, as follows:

$\begin{array}{ll}\text { Domestic Trunklines } & 95 . \mathrm{I} \% \\ \text { Class I Railroads } & 90.0 \\ \text { American Telephone and Telegraph Co. } & 87 . \mathrm{I} \\ \text { National Gas Companies } & 86.0 \\ \text { Class A and B Electric Companies } & 8 \mathrm{r.4}\end{array}$

${ }^{57}$ For the period $1951-56,20$ manufacturing companies had composite operating ratios which averaged 94.4\%. Id., Exhibit No. AA-902, Sept. 13, 1957. 
cent; but a similar five per cent reduction of the revenues of the airline, again with no change in cost, would cut its return by seventy per cent, to 1.8 per cent. ${ }^{58}$

Not only are airline revenues-for competitive and other reasons-more susceptible of miscalculation than those of an electric utility, for example, but operating costs also are, as a practical matter, particularly open to upward pressure due to the large element of labor cost, which, in the case of the airlines, amounts to over fifty per cent of the total cash expenses. ${ }^{59}$ When to these considerations are added the effects of small variations in load factors (which are to' a very considerable extent beyond the control of managiement) upön both revenues and unit costs, it can be seen that airline profits are especially liable to unpredictable fluctuation.

f. Instability of earnings. All the factors thus far mentioned have made airline earnings highly unstable over the years, strongly supporting the view that a relatively high level of return should be permitted in order to compensate for such a great degree of uncertainty. While the proposition that the profit element derives fromand is related to-the assumption of risk is in accordance with the canons of orthodox economic theory, ${ }^{\text {Bo }}$ it was deemed desirable in the instant proceeding to subject this maxim to factual test. Because of the problems of securing comparable data for unregulated businesses which would correspond to the "fair return" used for regulatory purposes, this was a matter of considerable difficulty. American suceeded, however, in assembling and analyzing a variety of financial data for the period, I93555 inclusive, covering 195 major unregulated concerns of interest to professional investors. ${ }^{61}$ So far as we are aware, no such comprehensive study had ever been presented in a rate case before any regulatory agency.

Without laboring the details of this study, the concerns were divided into thirtythree industrial groups, and for each, the financial data were aggregated, with rates of return being calculated for each group in each year. For each industry, a simple average of the annual earnings rates and the average annual deviations from that average were calculated. : These results were plotted, with the result that a definite and positive statistical relationship was shown between the levels and the instability of earnings. ${ }^{62}$ Stable industries typically had lower earnings than unstable industries. But when airline data were plotted similarly, it was found that the industries-such as aircraft and automobile-manufacturing-which had earnings as unstable over the years as those of the airlines enjoyed levels of return about twice as high. In sum,

${ }^{58}$ The details of these calculations àre set forth in id., Exhibit No. AA-402, Sept. $x 3,1957$.

${ }^{50}$ Id., Exhibit No. AA-32I, Sëpt.: 13, 1957.

${ }^{\circ}$ See, e.g., Frank H. Knight, Risk, Uncertainty, and Profit (Ig2I).

${ }^{61}$ For details as to the scope, methodology, and conclusions of this study, see CAB No. 8008, Exhibit No. AA-5, Testimony of W. Braddock Hickman, Oct. 25, 1957, and supporting Exhibits Nos. AA-500-04, Feb. 27, 1957, 800, Feb. 27, 1957, and x201, Feb. 13, 1958. This unique material was also used extensively in id., Eastern Air Lines Exhibit No. I-R, Testimony and Exhibits of Dr. Herbert B. Dorau, Oct. II, I957; id., Joint Exhibit for Braniff, Capital, Continental, Delta, and Western, Air Lines, Exhibits and Testimony of $\mathrm{J}$. Rhoads Foster, Oct. 25, 1957.

${ }^{62}$ Further corroboration of these conclusions has since become available. Sec Lanzillotti, Pricing Objectives in Large Companies, 48 Am. Econ. Rev. 921 (1958); Stdner Cottle \& Tate Whitrun, Corporate Earninc Power and Market Valuation, 1935-I955 (1959). 
the study furnished additional support for the twelve per cent rate of return sought, since that was approximately the average annual rate of earnings enjoyed by industries having similarly unstable earnings with which the airlines must compete for capital.

The testimony of a large number of independent financial experts was likewise to the effect that, for the airlines to raise the large amounts of capital which they required, investor confidence would have to be built upon far more stable and adequate earnings than they had enjoyed in the past. $^{63}$

\section{Rate of return}

In further support of the need for a rate of return in the order of twelve per cent to reflect the risk characteristics of the industry, extensive and uncontroverted evidence of its capital requirements was presented, together with testimony as to the "cost of capital," which might assist the Board in arriving at conclusions on this point. It is recognized that there are weaknesses in the derivation of a fair rate of return based solely on the historical cost of capital to the enterprise, particularly when earningsprice ratios developed from market valuations are applied mechanically to the usually lower book values representing the equity. ${ }^{64}$ The regulatory agencies, however, need some standard by which to judge the reasonableness of the dollar amounts or the rate of return sought in rate proceedings. If applied with a look to the future and as a basis for judgment, rather than as a strict mathematical formula grounded only in the past, "cost of capital" studies can be useful in this respect.

Accordingly, both the carriers and the Board's staff presented evidence from outside experts on this point. On both sides, the approaches had much in common, although the results differed, chiefly because of the use of different debt-equity ratios and different rates for both debt and equity capital. The principal expert witnesses for the carriers in this are ${ }^{65}$ arrived at rates of return in the order of twelve per cent or more by using desirable future debt ratios of twenty-five to thirty per cent, although conceding that these would have to be exceeded temporarily, whereas the Board's witness used forty per cent. ${ }^{66}$ The carriers' witnesses used a cost of four to five per cent on the debt, again looking to the future, against the Board's witness's four per

es For the Air Transport Association: Albert H. Gordon, Kidder, Peabody \& Co.; James P. Mitchell, Chase Manhattan Bank; Frederick F. Robinson, National Aviation Corp.; Arthur H. Tully, Jr., Hayden, Stone \& Co.; T. Carl Wedel, First National City Bank; and Percy S. Young, Jr., Prudential Insurance Co. For American: Benjamin S. Clark, White, Weld \& Co.; Edwin H. Herzog, Lazard Freres \& Co. For Braniff: Ferdinand Eberstadt, F. Eberstadt \& Co. For Trans World: T. W. Fowler, Merrill, Lynch, Pierce, Fenner \& Smith. For United: Franklin T. McClintock, Harriman, Ripley \& Co.

os The writer's views in this respect have been expressed before the National Federation of Financial Analysts Societies, noted in 5 I PuB. UTIL. ForT. 632 (1953). Logical circularity would be involved in arguing that rate regulation should be attuned to maintaining existing market values of securities; nevertheless, if competitive investor appeal is to be provided, equities must sell at substantial premiums above book value-the amount being a matter for expert judgment, not arithmetic. See also Report of Committee on Corporate Finance, in 70 Proceedings, National Association of Railroad and Utilities COMMISSIONERS 57 (1958).

- ${ }^{06}$ For American, W. C. Gilman, CAB No. 8008, Exhibits Nos. AA-4, Oct. 25, 1957, 900-27, Sept. 13, 1957; for United, David A. Kosh, id., United Air Lines Exhibit No. U-4, Oct. 25, 1957.

${ }^{66}$ Id., Bureau Counsel Exhibit No. I20, Testimony and Exhibits of Paul L. Howell, Oct. 15, 1957. 
cent maximum for the larger carriers and 4.8 per cent for the smaller. ${ }^{67}$ The carriers' witnesses estimated costs of equity, after allowance for financing cost, market pressure, and so forth, were fourteen to fifteen per cent, as compared with the Board's witness's figures of 12.9 per cent for the four major carriers and 14.I per cent for the smaller eight. On this basis, the Board's witness recommended rates of return in the range of nine to 9.7 per cent for the former and of 10.38 per cent for the latter.

In the brief to the examiner, however, Board counsel, using a debt ratio of fortyfive per cent for the larger and fifty per cent for the smaller carriers, advocated rates of return of 8.9 per cent for the former and 9.45 per cent for the latter. At no point in the proceeding has it been explained just how these differential rates of return would be applied-even if the unit costs of the small carriers were as low as those of the large-in fixing fare levels in situations where, for competitive reasons, charges would have to be identical if all were to share in the traffic.

The Board's staff also took a position adverse to the substitution of the operating ratio for the rate of return as the standard in determining the reasonableness of carrier earnings. It was pointed out that regulatory commissions utilizing operating ratio for transit systems and motor carriers ordinarily relate their findings also to the rate of return to be produced-frequently at quite high levels because of the very small investments involved. It is not believed, however, that the same objections can be raised to the use made of the operating ratio by United as a check upon the supportable debt ratio in terms of a safe coverage of charges by earnings, or by American as a supplement to the rate-of-return approach indicating a dangerous shrinkage of the margin of profit which could require re-examination of the adequacy of the fare level.

\section{Investment base}

Whatever rate of return is selected, obviously the dollar earnings allowed-and hence the practical consequences of the "end result"-will be equally dependent upon the rate base used. In airline practice, it has been customary to look to the investment as shown on the balance sheet, rather than to the physical assets, as the measure of net investment. And in mail-rate and subsidy cases, commonly applying to past periods, the $C A B$ has frequently disallowed deposits required to be made with manufacturers for equipment not yet delivered, on the grounds that such aircraft are not presently "used and useful" in serving the public. ${ }^{68}$ The Board also has ordinarily determined net investment by averaging the balances at the beginning and end of the test period, thus "matching earnings and investment."

Whatever merit these practices may have in airline subsidy cases or in publicutility regulation when the reasonableness of past charges is at issue for the purpose of determining refunds, the airlines submit that they have no proper place in the

\footnotetext{
${ }^{67}$ The propriety of using $5 \%$ as the measure of the cost of new borrowing is borne out by the fact that American announced, April 15, 1959, the borrowing of $\$ 30,000,000$ on notes due in 1996 and $\$ 40,000,000$ on subordinated convertible debentures, both bearing interest at $5 \%$. Aviation Daily, April 16, 1959, p. 334 .

${ }^{68}$ E.g., Pan American Airways, Transatlantic Mail Rates, 8 C.A.B. 267, 285-286 (1947).
} 
present proceeding, where the question is that of determining the level of fares and earnings which will be permissible for a considerable time in the future. Some of the regulatory agencies have faced up to the prospective nature of rate-making and have allowed for foreseeable increases in plant and investment, either directly in fixing the rate base ${ }^{69}$ or indirectly by allowing for attrition in the rate of return. ${ }^{70}$

In a protracted proceeding such as the General Passenger Fare Investigation, where the data of record cover a span of years in the history of an industry marked by continuing growth and confronted by vast increases of investment which are certain and imminent, not speculative or remote, there is every reason for using as the rate base not figures tied to averages in the past, but truly representing the funds and assets which will be devoted to the public service at the time when the fares to be prescribed will be effective. ${ }^{71}$ The record is replete with specifics as to the firm capital commitments which the airlines have made. Determination of a forwardlooking rate base, therefore, would not involve a great degree of either conjecture or difficulty. From the standpoint of sound administration, as well as equity, it seems clearly called for, since any other course could well result in fares which would be outmoded from the outset and, therefore, result in a further and unnecessary round of costly and time-consuming proceedings.

If the Board adopts this view of the matter and relates its findings to a rate base fairly reflecting the investment which the carriers must make to perform their continuing public-service obligation, the question of the treatment of equipment deposits can assume progressively diminishing practical significance. The further advanced the date as of which net investment is determined, the more of the aircraft represented by such deposits will have been delivered and placed in service. But on the merits, the fact is that, by long established industry-wide practice, any airline which wishes to secure and maintain a position on the manufacturers' schedules must conform to the requirements of progress payments during the course of manufacture which, at least in amount, duration, and impact, are unparalleled in the public utility field.

\footnotetext{
${ }^{\circ 0}$ See, e.g., Illinois Commerce Comm'n v. Natural Gas Pipeline Co., 2 F.P.C. 218, 228 (1940), aff'd, 315 U.S. 575 (1942), wherein an estimated capital outlay of nearly $\$ 4,000,000$ over a three-year future period was taken into account; Re Mountain States Tel. \& Tel. Co., I P.U.R. 3d 129, 133 (Colo. P. U. Comm'n 1953), where, on the basis of past experience and plans in the immediate foreseeable future, $\$ 6,000,000$ of plant under construction was included in the rate base; also $R e$ Berkshire Street Ry., 88 P.U.R. (n.s.) 21, 25 (Mass. Dep't P.U. I95I); Re Consolidated Edison Co., 96 P.U.R. (n.s.) 194, 216-I 8 (N.Y.P.U. Comm'n I952); Re Southwestern Bell Tel. Co., 2 P.U.R. 3d r, 8-9 (Ark. P.S. Comm'n 1953); Public Util. Comm'n v. Peoples Natural Gas Co., 6 P.U.R. 3d 341, 348 (Pa. P.U. Comm'n 1954); Re Illinois Bell Tel. Co., 7 P.U.R. 3d 493, 502 (Ill. Commerce Comm'n 1955); Re Arkansas Louisiana Gas Co., 7 P.U.R. 3d 594, 599 (Ark. P.S. Comm'n 1955); Re Potomac Elec. Power Co., 8 P.U.R. 3d 76, 90 (D.C. P.U.Comm'n 1955); Re Union Tel. Co,, 12 P.U.R. 3d 343 (Mich. P. S. Comm'n 1956).

${ }^{\circ}$ E.g., Re Mountain States Tel. \& Tel. Co., 2 P.U.R. 3d 75, 90 (Utah P.S. Comm'n r953); Re Southern Bell Tel. \& Tel. Co., I2 P.U.R. 3d I70, 197 (Tenn. P.S. Comm'n I956).

${ }^{71}$ This is the approach which, perforce, has to be taken by agencies such as the FPC when it is reviewing the economic feasibility of an entirely new pipeline project or the extension of an existing utility. See, e.g., Pacific Northwest Pipeline Co., 6 P.U.R. 3d 403 (FPC 1954); Texas Eastern Transmission Corp. and Texas Eastern Penn-Jersey Transmission Corp., I6 F.P.C. 27 (1956); and, of course, the CAB is confronted with similar situations in passing upon applications for new route authority.
} 
In the case of a typical electrical system, for example, such payments would amount to not much over one per cent of its total fixed capital at any one time, and ordinarily would represent an even smaller portion. For the airlines, however, at particular stages of the re-equipment cycle now in progress, equipment deposits may amount to as much as a quarter or a half of their total net investment in flight and ground equipment. At December $3^{\mathrm{r}}$, $195^{8}$, American alone had on deposit with manufacturers more than $\$ 59,000,000$, or over fifty per cent of its total net investment in flight equipment. ${ }^{72}$ Furthermore, because of the lead-time required in securing aircraft, funds so advanced are tied up, in varying amounts, for periods of as much as three years. Thus, it is estimated that on the basis of present firm orders and progress payment schedules, American will still have in the neighborhood of $\$ 53,000,000$ on deposit with manufacturers at the end of 1960 , or nearly twenty per cent of its projected net investment in flight and ground equipment at that time. ${ }^{73}$

While some airlines have been able to supplement their internally-generated funds by outside borrowing in order to meet the requirements of the manufacturers for advance payments, the fact remains that, whatever their source, such deposits are as truly a necessary part of the "stock in trade" of the enterprise-and just as properly included in the rate base under the circumstances of this proceeding-as are any other portions of the investment. They are equally exposed to all the hazards of the business and are equally entitled to earn the over-all return found commensurate with such risk. Nevertheless, the Board's staff, relying largely on precedents developed in the altogether different setting of mail-rate and subsidy cases, recommends the exclusion of these items-estimated for the trunkline industry at June $3^{\circ}$, I958, as more than $\$ 182,000,000-$ from the rate base. ${ }^{74}$

As the result of these and other "adjustments," the 1958 year-end industry-wide rate base recommended by the Board's staff becomes some $\$ 200,000,000$, or twelve per cent less than the investment recognized even by its outside expert witness. ${ }^{75}$ Taking into account also the staff's scaling down of its expert witness's recommended rate of return, the 1958 return advocated by the Bureau falls more than $\$ 25,000,000$ (20.7 per cent) for the industry, and over $\$ 5,500,000$ (26.4 per cent) for American, below the results of his recommendations ${ }^{78}$ - with the discrepancies, of course, becoming even larger when compared with the carriers' positions regarding the rate of return. Needless to say, it is the hope of the airlines that the Board will give more realistic recognition to the entire investment which they are, in fact, devoting to the public service. Unless this is done, upward revisions of the requested rates of return will

ig AMerican AirLines, INc., ANn. ReP., I958, at 10, I7.

${ }^{73} \mathrm{CAB}$ No. 8008, Exhibit No. AA-r107, Oct. 15, 1957.

"7 Id. Brief of Bureau Counsel to the Examiner, Oct. 29, 1958, p. 267, n. 42. Some slight concession is indicated in the direction of permitting the capitalization of some element of interest on cquipment deposits covering equipment to be delivered in the future, to a degree simulating the treatment of "interest during construction" in public-utility regulation. For the reasons stated in the text, however, it is believed that the two situations are so different, in magnitude and impact, that such relativcly minor allowances would fall far short of meeting the problem.

${ }^{75}$ Derived from CAB No. 8008, Exhibit BCR-930, 2d rev., Nov. II, I957.

${ }^{70}$ Ibid. 
be necessary to produce the dollar "end result" required by the airlines for competitive equality in the capital market.

\section{Projections of revenues and expenses}

Both the carriers and the Board's staff assert agreement on the principle that the entire case should be viewed not from a "keyhole" approach giving undue weight to temporary or atypical conditions in the past, but from an informed appraisal of what can reasonably be expected in the foreseeable future. In the application of this approach to projections of revenues and expenses through I96I, however, they are far apart. It is, of course, the duty of any regulatory agency to scrutinize carefully the estimates of costs and revenues submitted by the subject companies to determine whether they are reasonable and supportable in terms of what can be expected of honest and economical management. In so doing, they ordinarily use the immediate past as a guide and then try to give appropriate weight to "known changes" and those which may reasonably be anticipated. Nonrecurring items of both revenue and expense are, of course, excluded.

It is recognized, however, even in the relatively simpler areas of electric, gas, and telephone rate-making-where the commissions are dealing with the forecasts of but a single, noncompetitive supplier-that rate-making involves "a residual difference between two estimates. . . . If actual revenues received ot actual operating expenses should deviate . . . in only small degree, the resulting effect on return could be very considerable."i7 Because of this, and because of the fact that both the expertise and the responsibilities of regulator and manager are vastly different, the former usually proceeds with caution in substituting its judgment for that of the latter. "Adjustments" of the good-faith forecasts of management, therefore, are not made unless well-supported by convincing proof; and ordinarily they are relatively small in relation to the totals involved. In the case of the airlines, where severe competition exerts a powerful check on the course of costs and where the present is so precarious and the future so uncertain, the exercise of such caution and restraint would appear particularly appropriate. Nevertheless, in the instant proceeding, the Board's staff has attacked the estimates of the carriers with what seems to resemble reckless abandon. ${ }^{78}$

Speaking broadly, the "adjustments" proposed by the Board's staff fall into four crucial areas, in addition to those of rate of return and rate base, which have been dis-

${ }^{77}$ United Fuel Gas Co., 12 F.P.C. 25x, 270 (1953).

${ }^{78}$ In the carlier stages of the General Passenger Fare Investigation, it appeared that the Board's staff was preparing to contend that since at times in the past certain carriers had enjoyed substantial capital gains from the sale of used flight equipment, possible future gains of this character should be included in the projections of revenues. To this, the airlines took strong exception, pointing out that not only would any such gains have no proper place among the operating revenues to which fares are related, but also that the uncertainties surrounding the disposition of large numbers of piston-engined aircraft upon their supersession by jets made any estimates of gains from this source little more than wild guesses. It now appears that Bureau counsel has arrived at a position close to that of the carriers-i.e., that any net capital gains which may materialize should be viewed merely as a potential cushion in meeting the airlines' capital needs, and should not be relied upon for rate-making purposes. 
cussed above. These involve the treatment of depreciation expense, income taxes, load factor, and passenger revenue yield.

a. Depreciation. As to depreciation, so far as projected costs associated with the new turbine-engined equipment are concerned, the carriers and the Board's staff differ only with respect to the engines. On the airframes, ten-year service lives and fifteen per cent residual values are acceptable to both. The Board's staff would use the same basis for the engines; the airlines, however, anticipating early and substantial engine improvements, would use service lives of only five years, with a fifteen per cent residual value for the jets and zero residual value for the turboprop engines. Engineering developments to date fully support the judgment of the carriers in this respect.

On piston-engined aircraft, the carriers generally have used for accounting purposes seven-year service lives and ten per cent residual values, without objection by the Board or its staff until recently, when an unsuccessful effort was made to prescribe uniform depreciation rates based on higher residual values. ${ }^{70}$ For American, for example, this meant that its DC-7 aircraft would be written off the books in Ig6r, except for those delivered in 1956, 1957, and 1958. As to these, American had established shorter service lives so as to bring about a substantially common retirement date, since it was anticipated that the entire fleet of this type aircraft would become obsolete for its use with the transition to full jet operation.

Although the Board's staff's position seems to have undergone several changes during the course of the case, in computing projected costs per available ton-mile, it has used an over-all industry figure of 2.45 cents for flight equipment depreciation, ${ }^{80}$ which is only about seventy-three per cent of the amount estimated by the carrier to be required. Obviously, the exposure of the carrier and its stockholders to retirement losses would be greatly increased if fares were to be based on a grossly inadequate provision for depreciation. No such drastic revision of managerial judgment should be made without much more convincing evidentiary support than can be found in the record.

b. Income taxes. Advantage has been taken by the carriers generally of the provisions for "liberalized depreciation" and "accelerated amortization" contained in sections 167 and 168 of the Internal Revenue Code of 1954 . They contend that there is nothing in the legislative history of these sections which indicates an intent to discriminate against regulated businesses or to deny them the benefits which Congress intended. It is their position that the result of utilizing these methods is a deferral, not a saving, of income taxes. 81 Accordingly, they have "normalized" their charges

${ }^{\text {ig }}$ The courts have held that the CAB lacks authority to prescribe depreciation, Alaska Airlines $v$. $\mathrm{CAB}, 257$ F.2d 229 (D.C. Cir.); cert. denied, $35^{8}$ U.S. 88I (1958). American has, nevertheless, adopted for accounting purposes the Board's position as to residual values, but not as to the service lives of these aircraft. American Airdines, Inc., AnN. Rep., 1958, at p. 19, n. 9.

${ }^{80} \mathrm{CAB}$ No. 8008 , Exhibit BCR-850, 3 d rev. July 22, 1958.

${ }^{81}$ Relying largely upon the practices of the FPC and a number of state regulatory agencies. Sec, e.g., Panhandle Eastern Pipe Line Co., 3 P.U.R. 3d 396 (FPC 1954), remanded on other grounds, City of Detroit v. FPC, 230 F.2d 810 (D.C. Cir. 1955); Amere Gas Util. Co., I5 F.P.C. 76o (1956); Re Okla- 
for depreciation on the books and have earmarked the tax difference in reserves for deferred income taxes.

The Board's staff does not now quarrel with the principle of normalization in so far as accelerated amortization under section r68 is concerned, but it does object to the same procedure as to liberalized depreciation under section 167.92 In the case of American, the impact of this adjustment, when combined with the Board's recommended rate base and rate of return, is to reduce the projected cost per available tonmile to 1.89 cents, or only about forty per cent of the unit cost projected by the carrier, in this category.

c. Load factor. In making its long-range estimates of revenues and expenses, American has used a sixty-five per cent load factor, while the Board's staff has employed a "reasonably attainable" figure of sixty-seven per cent. Although this may, at first glance, appear to be but a slight difference, the fact is that, in terms of the projections of this one carrier alone, each load factor percentage point represents ro5,000,000 revenue-passenger-miles, or $\$ 5,600,000$ annually at I957 fare levels and $\$ 6,400,000$ at the fare levels requested in the proceeding.

Here, again, of course, is a matter which involves expert judgment, not one of demonstrable fact. The Board's staff's position is grounded primarily on carrier performance during a five-year period in the past, when the character of service was deemed adequate and efficient, and on the proposition that management can closely control the results of operations in this respect. As a matter of operational and financial planning and efficiency, every airline must watch its load factors closely, and on a segment-by-segment basis. If they fall too low, operations are unprofitable; if they rise too high, service suffers because of inability to carry passengers where and when they want to travel. But here there are numerous elements which inhibit the ability of management to keep its load factors at the precise levels which might be most desirable from the standpoint of profits.

One of these limitations is the fact that seats have to be added or eliminated in groups representing the capacity of the aircraft: forty, sixty, eighty, or, with the jets, I00 or more. Thus, changes of schedules-quite apart from their impacts upon the convenience of the traveling public and, therefore, upon total demand-cannot be finely adjusted to minor variations of traffic volume which affect resulting load factors. Another is the fact that because of their public-service obligations as well as

homa Natural Gas Co., I2 P.U.R. 3d 293 (Okla. Corp. Comm'n I955); Re Public Service Co., I2 P.U.R. 3d 509, 515 (Ind. P. S. Comm'n I956); Re General 'Tel. Co., 14 P.U.R. 3d 243 (N.M. State Corp. Comm'n r956); Re La Crosse Tel. Corp, 20 P.U.R. 3d 94 (Wis. P. S. Comm'n r957); Re Western Ky. Gas. Co., 21 P.U.R. 3d 394, 399-400 (Ky. P.S. Comm'n I957); Re Alton Water Co., 22 P.U.R. 3d 358, 364-66 (Ill. Commerce Comm'n I958); Re Michigan Cons. Gas Co., 22 P.U.R. 3d 369, 377-79 (Mich. P. S. Comm'n I958); Re Empire Dist. Elec. Co., 23 P.U.R. 3d 45, 49-53 (Kan. State Corp. Comm'n 1958); Re United Tel. Co., 23 P.U.R. 3d 68, 75-77 (Wyo. P.S.Comm'n 1958). See also Guercken, Economic and Regulatory Aspects of Accelerated Depreciation, 58 PUB. UTIL. Font. I45 (1956).

${ }_{82}$ The writer is unable to distinguish between these provisions, in terms of legislative intent, in so far as their regulatory aspects are concerned. See, e.g., House Comm. on Ways and Means, Internal Revenue Code of 1954, H.R. REP. No. 1337, 83d Cong., 2d Sess. (I954); Senate Comm. on Finance, internal Revenue Code of 1954, S. REP. No. I622, 83d Cong., 2d Sess. (I954). 
for competitive reasons, there is an irreducible minimum level at which service must be maintained if a carrier is to remain in a given market. Furthermore, the necessity of achieving efficient utilization of available aircraft and of locating equipment where it is needed limits scheduling flexibility, as does the need for providing convenient through service and connecting schedules, apart from the local traffic on the particular segment in question.

These are some of the fàctors with which management has to contend in tailoring its schedules to meet the public need. And all are reasons why actual results in the uncertain future of the jet age may fall considerably short of what might theoretically be possible in terms of different conditions which have prevailed in the past. Again, the record affords no substantial basis for upsetting the judgments of management, based upon detailed segment-by-segment analysis, as to probable load factors in the future.

d. Passenger revenue yield. In projecting revenues into the future, the Board's staff has applied to forecasted traffic the current yields per passenger-mile. Some carriers, on the other hand, have taken into consideration the depressing effect upon this average of the anticipated increase in the proportion of traffic which will be represented by coach travel at lower fares. In the case of American, the difference per unit again appears small-only 0.05 cents per passenger-mile-but in the aggregate, it becomes substantial-more than $\$ 3,400,000$ annually in terms of the average traffic level projected over a three-year period.

Since coach traffic has grown at a much greater rate than first-class traffic in recent years, and since the record shows that the equipment and scheduling plans of the carriers definitely provide for the continuation of this trend, it seems clear that here we have a matter which can be characterized as the type of "known change" that the Board cannot reasonably disregard.

Taking all these "adjustments" into account-together with others which, because their impacts are less significant, have not been noted here-we find that, in the case of American, they amount in toto to reductions of projected passenger costs per available ton-mile of 3.01 cents (or 0.79 cents per revenue-passenger-mile) and to increases of projected passenger revenues of 1.05 cents per available ton-mile ( 0.05 cents per revenue-passenger-mile). Translated into total dollars on an annual basis, this represents for American a total dollar difference of about $\$ 58,000,000 ;^{83}$ a comparable figure for the domestic operations of United is approximately $\$ 65,000,000 .^{84}$

\section{V}

\section{Conclusion}

Unfortunately, the limitations of space make it impossible to explore other interesting facets of the problems presented to the airline industry and the $C A B$ in the General Passenger Fare Investigation. Among them are the questions, how can a

${ }^{82}$ CAB No. 8008, American's Brief to the Examiner, Oct. 29, $x 958$, p. $x \times 6$.

${ }^{8 s}$ Information furnished by United Air Lines in response to the writer's request. 
comprehensive proceeding such as this be brought to a conclusion within a shorter time-span than over three years, during which there is always a danger that much of the record will become stale and of diminished usefulness; and how, after differences between the carriers and the staff of the magnitude indicated above have been resolved by the examiner and the board, should the results be applied to the fare level-whether in terms of the needs of the strongest carriers, upon the requirements of the weakest carriers, or upon some composite or "bellwether"85 basis.

Another matter which it has not been possible to explore is the weight which should be accorded to "value of service" considerations in a proceeding involving the general level of fares. In the instant case, there has been some probing into the probable elasticity of demand, with the carriers contending that, within the limits of the general increases sought, there is no reason to suppose that traffic would be adversely affected. This, no doubt, is a matter which will be more directly at issue in such fare relationship proceedings as may follow the conclusion of the General Passenger Fare Investigation.

It is hoped, however, that the foregoing pages will have served to convey to the reader an understanding of the basic issues present in the pending case, which is of such vital importance to the future of the airline industry in the United States. As stated toward the outset, it is the writer's view that a proper application of the "fair return" concept will afford sufficient flexibility for the sound resolution of these issues. What seems to require recognition, above all else, is the fact that, in applying established principles of regulation to the airlines, due weight should be given to the characteristics which distinguish them from the usual types of public utility. ${ }^{80}$

\section{ADDENDUM}

Shortly after the foregoing article was submitted for publication, Examiner Ralph L. Wiser issued, on May 27, 1959, his initial decision in the General Passenger Fare Investigation. Because the issues in the proceeding are referred to so extensively in the article, it is believed that the following brief summary of the examiner's opinion will be of interest and service to the reader.

While the examiner's conclusions differ in some respects from those of the article, there is a remarkable similarity in these two analyses of the basic problems presented by the case. Thus, the examiner applies to airline fare regulation the "fair return" approach, holding that rate of return on investment is a legal, practicable, and efficient standard for measuring risk in this setting, and that operating ratio or return margin-while a useful tool in appraising variations in earnings-cannot be taken as the measure of the reasonableness of charges independently of the return on investment which they will produce.

\footnotetext{
${ }^{80}$ In the Matter of Western Union Telegraph Co., No. II953, Initial Decision Made Final, FCC, July 30, ז958, pp. 48-55.

so "The airline industry is in many respects different from the usual public utility, and I feel that sound regulation requires careful consideration of its peculiar characteristics." Address of CAB Member Louis J. Hector, Problems in Economic Regulation of Civil Aviation in the United States, before the New York Socicty of Security Analysts, Nov, 28, x958.
} 
In applying this standard, the examiner concludes that due to competitive factors and earnings instability, the airlines are in a much greater risk position than are the conventional nontransportation utilities and, therefore, require a substantially higher profit allowance. Based upon the evidence as to costs of capital and prospective debt-equity ratios, he finds that an over-all industry rate of return of 10.6 per cent would be fair; but he recognizes that a uniform and stable fare level would inevitably lead to somewhat divergent results from carrier to carrier and from time to time. Accordingly, he concludes that five-year average returns ranging from ten to twelve per cent would be reasonable. In support of this view, he holds that "the continued health of the air carriers is more important to the public interest than any squeezing of a small number of percentage points out of the fare level."

The examiner would allow his fair rate of return on a "prudent investment" rate base derived from the right-hand side of the balance sheet and excluding only those items of net investment found to be dishonest or obviously wasteful or imprudent expenditures. Having found the jet acquisition programs of the carriers to represent honest, economical, and efficient management, he reasons that equipment deposits prudently made are to be recognized as part of the rate base. Reserves for deferred federal income taxes are excluded as not representing investment by the stockholders or contributors of debt capital. Among the expenses to be recognized for rate-making purposes, however, federal income taxes are calculated on the basis of straight-line depreciation, regardless of the "accelerated" or "liberalized" methods used in computing the tax currently paid, thus giving effect to the congressional intent to confer a tax benefit.

In general, the examiner finds the operating plans, the traffic and revenue forecasts, and the load-factor estimates of the carriers to be reasonable. He rejects the $\mathrm{CAB}$ staff's proposed use of standard costs and load factors for a hypothetical future period as unjustified from the standpoint of either law or economics, and in this connection, he relies heavily upon the holding of the Court of Appeals for the District of Columbia in American Overseas Airlines, Inc. v. CAB, ${ }^{87}$ to the effect that the Board is not free to substitute its tests for those of the statute, or its standards for the managerial judgments and expense forecasts of the carriers, unless their operating plans are shown to be dishonest, inefficient, or uneconomical. He holds that the carrier estimates of future unit costs are somewhat too high-principally because he believes that increased productivity will be a stronger factor than rising prices during the next few years-and that depreciation on flight equipment should be treated on a uniform basis, resulting in some downward revisions of carrier figures for pistonengined equipment, although he does not suggest as drastic reductions as those proposed by the staff.

Based on his analysis of the various facets of the case, the examiner finds that the general level of domestic trunkline air fares should be increased by twelve per cent above the level in effect prior to February 10, 1958. To bring about this result,

${ }^{87}{ }_{274}$ F.2d 744 (D.C. Cir. 1958 ). 
RETURN ON INVESTMENT

Domestic Trunklines-Domestic Operations

First Nine Months I959-First Nine Months 1958

(THOUSANDS)

\begin{tabular}{|c|c|c|c|c|c|c|}
\hline & \multicolumn{3}{|c|}{ Frrst Nine Montins 1959} & \multicolumn{3}{|c|}{ FrRst Nine Months 1958} \\
\hline & $\begin{array}{c}\text { Net Profit } \\
\text { Before Interest } \\
\text { and After Taxes } \\
\text { Excl. Capital } \\
\text { Gains } \\
\end{array}$ & $\begin{array}{c}\text { Average } \\
\text { Domestic } \\
\text { Investment }\end{array}$ & $\begin{array}{l}\text { Return on } \\
\text { Investment }\end{array}$ & $\begin{array}{c}\text { Net Profit } \\
\text { Beforc Interest } \\
\text { and After Taxes } \\
\text { Excl. Capital } \\
\text { Gains }\end{array}$ & $\begin{array}{c}\text { Average } \\
\text { Domestic } \\
\text { Investment }\end{array}$ & $\begin{array}{l}\text { Return on } \\
\text { Investment }\end{array}$ \\
\hline $\begin{array}{l}\text { American...... } \\
\text { Eastern ...... } \\
\text { Trans World.. } \\
\text { United....... }\end{array}$ & $\begin{array}{r}\$ 14,496 \\
7,723 \\
11,878 \\
15,672\end{array}$ & $\begin{array}{l}282,982 \\
206,471 \\
131,041 \\
256,884\end{array}$ & $\begin{array}{c}6.8 \% \\
5.0 \\
12.1 \\
8.1\end{array}$ & $\begin{array}{r}\$ 12,611 \\
9,599 \\
2,737 \\
12,567\end{array}$ & $\begin{array}{r}201,631 \\
172,594 \\
128,448 \\
207,445\end{array}$ & $\begin{array}{l}8.3 \% \\
7.4 \\
2.8 \\
8.1\end{array}$ \\
\hline Subtotal. & $\$ 49,769$ & $\$ 877,378$ & $7.6 \%$ & $\$ 37,514$ & $\$ 710,118$ & $7.0 \%$ \\
\hline 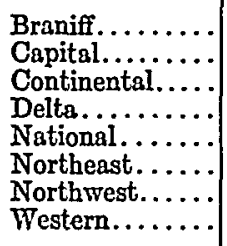 & $\begin{array}{r}\$ 2,455 \\
888 \\
2,257 \\
3,073 \\
1,434 \\
(2,717) \\
2,851 \\
4,228\end{array}$ & $\begin{array}{r}45,753 \\
61,548 \\
53,509 \\
66,209 \\
61,265 \\
24,456 \\
62,167 \\
41,772\end{array}$ & $\begin{array}{c}7.2 \% \\
1.9 \\
5.6 \\
6.2 \\
3.1 \\
(14.8) \\
6.1 \\
13.5\end{array}$ & $\begin{array}{r}\$ 2,000 \\
1,959 \\
383 \\
1,695 \\
411 \\
(4,751) \\
1,249 \\
(898)\end{array}$ & $\begin{array}{r}43,786 \\
63,225 \\
34,384 \\
59,334 \\
41,706 \\
19,417 \\
45,170 \\
34,427\end{array}$ & $\begin{array}{c}6.1 \% \\
4.1 \\
1.5 \\
3.8 \\
1.3 \\
(32.6) \\
3.7 \\
(3.5)\end{array}$ \\
\hline Subtotal & $\$ 14,469$ & $\$ 416,679$ & $4.6 \%$ & $\$ 2,048$ & $\$ 341,449$ & $0.8 \%$ \\
\hline Total Trunklines & $\$ 64,238$ & $\$ 1,294,057$ & $6.6 \%$ & $\$ 39,562$ & $\$ 1,051,567$ & $5.0 \%$ \\
\hline
\end{tabular}

() Denotes Loss.

Notes: (1) Investment-Corresponds with method of Examiner Wiser in the General Passenger Fare Investigation (long-term debt and stockholder's equity allocated to domestic operations on the basis of the ratio of domestic to total operating expenses; equipment deposits are included, reserves for deferred income taxes are excluded).

(2) Net Profi-First nine months 1958 - includes $4 \%+5 t$ only from February 10.

First nine montbs 1959 - includes discount elimination and jet surcharges Capital gains less income tares at $25 \%$ are excluded from the net profit

(3) Rate of Return-Compares with Examiner Wiser's recommendation of $10.25 \%$ for the "Big Four" and $11.25 \%$ for the "Smaller

Eight" and $10.6 \%$ for the industry.
Source: Form 41 'B submitted to the CAB.

he recommends that the temporary increases granted during the course of the proceeding (four per cent plus one dollar per ticket, effective February 10, I959, estimated to increase industry revenues by 6.6 per cent, and the various discount eliminations and reductions, effective October 20, 1958 , estimated to represent a 3.5 per cent increase) and then due to expire July $3 \mathrm{I}$, $x 959$, be made permanent. To meet the remainder of the carriers' needs, he suggests the addition of a further surcharge of one dollar per ticket, plus such small percentage changes in the present fare level as might turn out to be required. He concludes that such a modest fare increase would not have a substantial adverse effect on the volume of traffic.

Exceptions to the examiner's initial decision were filed June 8, and briefs to the Board July I5, with oral argument held on July 28 and 29, 1959. In the interim, the Board announced, by press release dated June 18 , that it would permit extension of the expiration dates on the tariffs conferring temporary relief from July 3 I through December $3 \mathrm{x}$, 1959 , to preserve the status quo pending final decision in the General Passenger Fare Investigation. 
Despite repeated references by the Board to the fact that this was to be an expedited case, its opinion and order disposing of this $3^{1 / 2}$-year-old proceeding have not yet been issued, nor is there any present indication as to when they will be. Although the earnings of the domestic trunklines for 1959 to date are, on the whole, considerably better than they were during the corresponding months of 1958 (due in part to the resumption of high rates of traffic growth and in part to increased revenue yields resulting from the interim fare relief granted by the Board and from the jet surcharges collected by the carriers which have thus far inaugurated jet service), they are still below the levels found reasonable by the examiner.

The above table shows that, for the first nine months of 1959, net profits (excluding capital gains and taxes related thereto) before interest and after taxes were generally more satisfactory than for the corresponding period in 1958 . Using the same method of computing the investment rate base as that followed by the examiner, rates of return rose from seven per cent to 7.6 per cent for the "Big Four," from 0.8 per cent to 4.6 per cent for the "Smaller Eight," and from five per cent to 6.6 per cent for the domestic trunkline industry as a whole. But these ratios were still far short of the ro.25 per cent, Ir.25 per cent, and ro.6 per cent, respectively, which he found appropriate.

With continued increases in traffic, those earnings are likely to improve further, but it would appear that there is still room for the additional fare increases which he recommended for consideration. And the behavior of the traffic under the interim increases and jet surcharges already made effective indicate that the demand is sufficiently inelastic to permit this. 